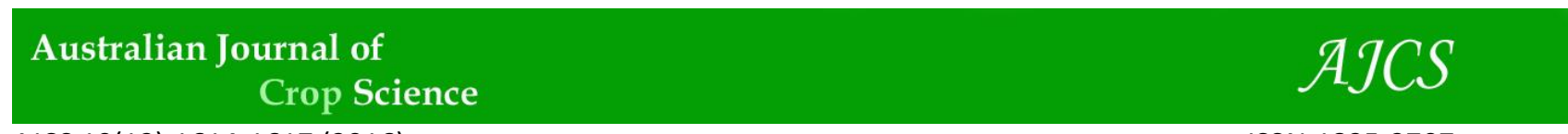

AJCS 10(12):1614-1617 (2016)

ISSN:1835-2707

doi: 10.21475/ajcs.2016.10.12.PNE117

\title{
Germination and initial growth of crambe (Crambe abyssinica Hochst.) under saline conditions
}

\author{
Laerte G. Pivetta ${ }^{1}$, Laércio A. Pivetta ${ }^{2}$, Gustavo Castoldi ${ }^{3 *}$, Mariângela B. Freiberger ${ }^{3}$, Maurício D. \\ Zanotto $^{4}$, Roberto L. Villas Bôas ${ }^{4}$
}

${ }^{1}$ Instituto Federal do Mato Grosso (IFMT). Sorriso, MT, Brazil

${ }^{2}$ Universidade Federal do Paraná (UFPR). Palotina, PR, Brazil

${ }^{3}$ Instituto Federal Goiano / Rede Arco Norte. Rio Verde. GO, Brazil

${ }^{4}$ São Paulo State University (UNESP), College of Agricultural Sciences. Botucatu, SP, Brazil

*Corresponding author: gustavo.castoldi@ifgoiano.edu.br

\begin{abstract}
Crambe is a promising crop for Brazil owing to its tolerance to drought and its short growing season (particularly if cultivated between seasons). However, the salinity tolerance of the unique Brazilian cultivar is not yet known. In this study, we aimed to determine the effects of different salinity levels on germination and initial growth of crambe cultivar FMS Brilhante. Therefore, an experiment was carried out in a completely randomized block design, during 19 days under greenhouse conditions. The treatments consisted of six levels of electrical conductivity of the soil saturation extract (EC): 2.50, 3.15, 3.35, 4.25, 5.75 and $9.55 \mathrm{dS}^{-1}$, obtained by adding sodium chloride $(\mathrm{NaCl})$ to soil. It was evaluated germination, germination speed index (GSI), length of roots and dry mass of shoot and roots. Overall, germination and GSI increased under low levels of salinity - up to $3.77 \mathrm{dS} \mathrm{m}^{-1}$, caused by a possible break effect in seed dormancy. The initial growth was more sensitive to salinity than seed germination and the shoot dry matter decreased linearly with increasing salinity levels, indicating that FMS Brilhante cultivar is moderately sensitive to salinity.
\end{abstract}

Keywords: Crambe abyssinica Hochst., FMS Brilhante, oilseed crop, electrical conductivity, dry matter. Abbreviations: EC_electrical conductivity; GSI_ germination speed index.

\section{Introduction}

Salt-affected soils can be defined as soils on which the growth of most crop plants is limited by an excess of readily soluble salts. Salts are considered readily soluble when its solubility in water is higher than gypsum. The salt concentration in the soil solution is usually measured by the electrical conductivity of the soil saturation extract (EC) (Eynard et al., 2005). A soil is saline when the EC of the extract is $>4 \mathrm{dS} \mathrm{m}^{-1}$ (SSSA, 1997). The effects on plant growth due to excessive concentrations of soluble salts in the root zone may be measured by osmotic inhibition of water absorption, or by specific effects of the ion component in the saline medium, or as combination of both. Furthermore, effects of specific ions may involve direct toxicity or a variety of nutritional effects (Bernstein and Hayward, 1958). Salinity is one of the major factors limiting agricultural productivity in arid and semi-arid regions (Ionov et al., 2013). Irrigation has resulted in the accumulation of salts to above-normal concentrations in the rooting zone of arable land, as high rates of evaporation and transpiration draw soluble salts from deep layers of the soil profile (Rozema and Flowers, 2008). Unfortunately, soil salinization in arid regions is practically irreversible because fresh water is not available to leach any accumulated salts (Rozema and Flowers, 2008). Plant breeding has been used for the production of stress tolerant crops, however, breeding has the limitation due to low magnitude of variation in gene pools of most crops (TURAN et al., 2012). Based on that, it's clear the importance of finding new potential plants with tolerance to salinity that can be used in agriculture. According to Vinocur and Altman (2005), the plant's response to salinity includes avoidance and tolerance mechanisms. Avoidance mechanisms are mainly result of morphological and physiological changes at the whole-plant level, but are less amenable to practical manipulations (Vinocur and Altamn, 2005). Tolerance mechanisms are caused by cellular and molecular biochemical modifications that can be more easely manipulated. Salinity tolerance is usually connected to keep a high concentration of necessary ions like $\mathrm{K}+$ and at the same time keep the concentration of toxic ions like $\mathrm{Na}+$ below a threshold level of toxic ions in cytosol (Bahmani et al., 2015). Plants can do this by adjusting the expression and activation of $\mathrm{K}+$ and $\mathrm{Na}+$ transporters and of $\mathrm{H}+$ pumps generating the driving force to transport (Bahmani et al., 2015). Crambe (Crambe abyssinica Hochst.) belongs to the Brassicaceae family and is native of the Mediterranean area. It s an oilseed crop that produces inedible oil used for industrial purposes (Oplinger et al., 1994). It has been reported as a promising crop in Argentina owing to its high tolerance to drought and cold and to its very short growing season; it blooms at 35 days and can be mechanically harvested at 90 days (Falasca et al., 2010). Paulose et al. (2010) found a putative cation transporter associated protein $(\mathrm{ChaC})$ in Crambe abyssinica cDNA. This protein has homology to the protein OsARP, which is highly expressed in rice under submergence, salt and 
drought stress (Qi et al., 2005) and stimulate salt tolerance when overexpressed in tobacco (Uddin et al., 2008).

Crambe may be a promising oilseed crop in Brazil as well, especially if cultivated between seasons when the rainfall is lower. The Fundação MS in Maracajú, on the State of Mato Grosso do Sul, released the first Brazilian cultivar of crambe in 2007, named FMS Brilhante (Pitol et al., 2010), but its salt tolerance is not yet known. Both Fowler (1991) on the basis of germination of the Meyer cultivar, Francois and Kleiman (1990) based on yield of five cultivars and three germplasm releases, and Ionov et al. (2013) based on a 2-year greenhouse experiment with irrigation using saline water, classified crambe as moderately tolerant to salinity. In this study we aimed to determine the effects of different salinity levels on germination and initial growth of crambe, cultivar FMS Brilhante.

\section{Results and Discussion}

\section{Germination and germination speed index}

There was a significant effect of treatments on germination and GSI (Fig. 1a, b). An improvement in both measurements on the first levels of salinity can be observed. This may have been caused by the presence of dormancy in the seeds. As crambe is barely domesticated, it exhibits a post-harvest dormancy (Carlson et al., 1996). There are indications that recently harvested seeds show primary dormancy since seeds that have not been stored have low germination rates (Costa et al., 2012a; 2012b). Post-harvest dormancy is a typical mechanism in undomesticated species to improve longevity and success, but in annual crops such a feature makes it difficult to accurately estimate germination percentages and it can lead to emergence of volunteer plants in the field several years after the crop is harvested (Carlson et al., 1996).

Franke and Nabinger (1996) argue that many salts, such as potassium nitrate $\left(\mathrm{KNO}_{3}\right)$, when in contact with pericarp, possibly softening it and facilitating gas exchange. The potassium nitrate is efficient in breaking seed dormancy in some species: e.g., Avena fatua L., Avena sativa L., Hordeum vulgare L. (Garber et al., 1974) and Carica papaya (Tokuisha et al., 2007). A similar event might had occurred in this study, and sodium chloride $(\mathrm{NaCl})$ could have played as a dormancy breaker.

The germination decreased $30 \%$ from $4.25 \mathrm{dS} \mathrm{m}^{-1}$ to 9.55 $\mathrm{dS} \mathrm{m}{ }^{-1}$ (Fig. 1a). Fowler (1991) observed $<10 \%$ reduction in germination, in this range of salinity, at $25^{\circ} \mathrm{C}$. The progressive decrease in germination with increasing osmotic pressure of the external solution can be explained in terms of classical osmotic theory by the decrease in diffusion pressure gradient between the medium and the plant (Bernstein and Hayward, 1958).

The decrease in GSI from $4.25 \mathrm{dS} \mathrm{m}^{-1}$ to $9.55 \mathrm{dS} \mathrm{m}^{-1}$ was $40 \%$ (Fig. 1b). Thus it would be possible seeing plants with delayed emergence in the field. Uneven emergence is worse than gaps in the production field; in corn, plants next to a gap demonstrate compensatory growth, whereas plants adjacent to a late-emerging corn plant do not exhibit this behavior (Liu et al., 2004).

\section{Root length, root dry matter and shoot dry matter}

There was a significant effect of treatments on root length, root dry matter and shoot dry matter (Figures 2 and 3). The root length decreased $65 \%$ between $4.25 \mathrm{dS} \mathrm{m}^{-1}$ and $9.55 \mathrm{dS}$ $\mathrm{m}^{-1}$ (Fig. 2a), and the decrease in root dry matter was $69 \%$ (Fig. 2b). Excessive concentrations of soluble salts in the
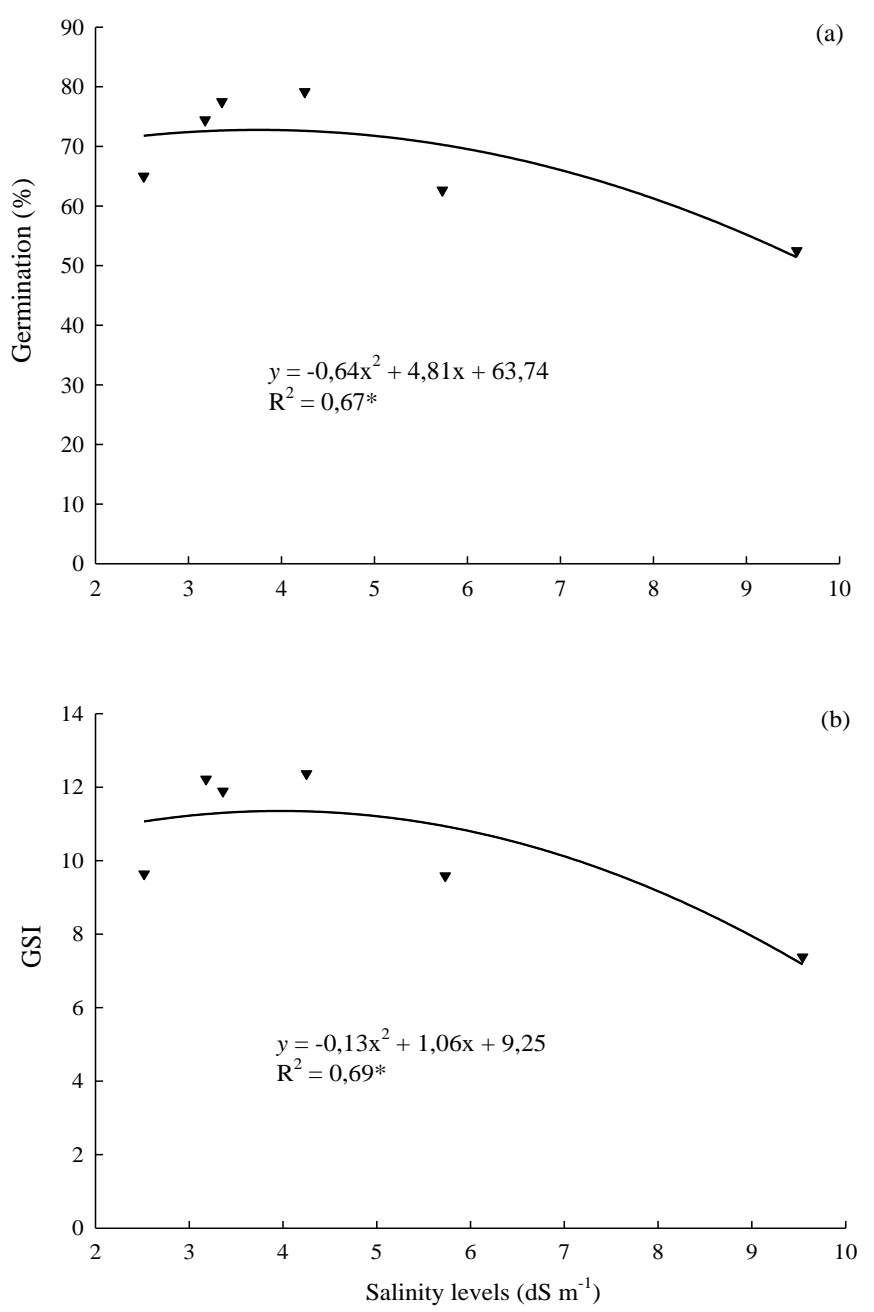

Fig 1. Germination (a) and germination speed index (b) of crambe (Crambe abyssinica Hochst.) as affected by salinity levels. Botucatu - SP, Brazil, 2012. *, significant at 5\%; **, significant at $1 \%$.

rhizosphere inhibits the absorption of water due to osmotic potential reduction of soil (Bernstein and Hayward, 1958). As salt concentrations increases above a threshold level, both the growth rate and the final size of most plant species progressively decrease (Mass and Hoffman, 1977).

A significant effect in the shoot dry matter was observed, with a $72 \%$ decrease between $3.15 \mathrm{dS} \mathrm{m}^{-1}$ and $9.55 \mathrm{dS} \mathrm{m}^{-1}$ (Fig. 3). Compared to root, the above part of the plant was more sensitive to salt, with a linear decrease in the dry matter, whilst for germination, GSI, root length and root dry matter were observed a maximum point. One explanation is that a reduction in leaf area development relative to root growth would decrease water use by the plant, thus allowing it to conserve soil moisture and prevent an escalation in the soil salt concentration (Munns and Tester, 2008). Another explanation is that roots possess markedly lower osmotic pressures than the above-ground parts, and the osmotic pressures do not vary nearly as much as in the latter with increasing salinity of the root medium (Bernstein and Hayward, 1958).

As it has been observed, despite the fact that germination values seem little affected by salinity, the vegetative growth characteristics were more affected, particularly in the shoots. 

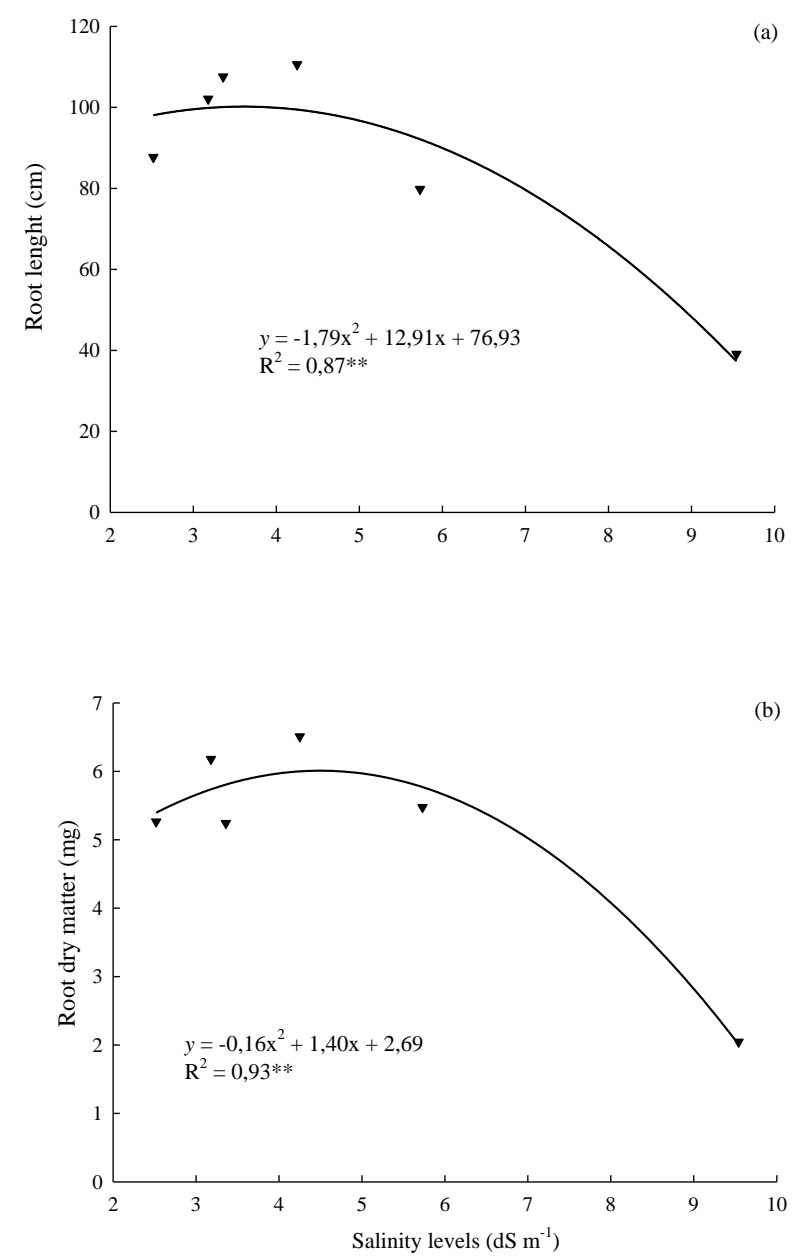

Fig 2. Root dry matter and root length of crambe (Crambe abyssinica Hochst.) grown under different salinity levels. Botucatu - SP, Brazil, 2012. *, significant at 5\%; **, significant at $1 \%$.

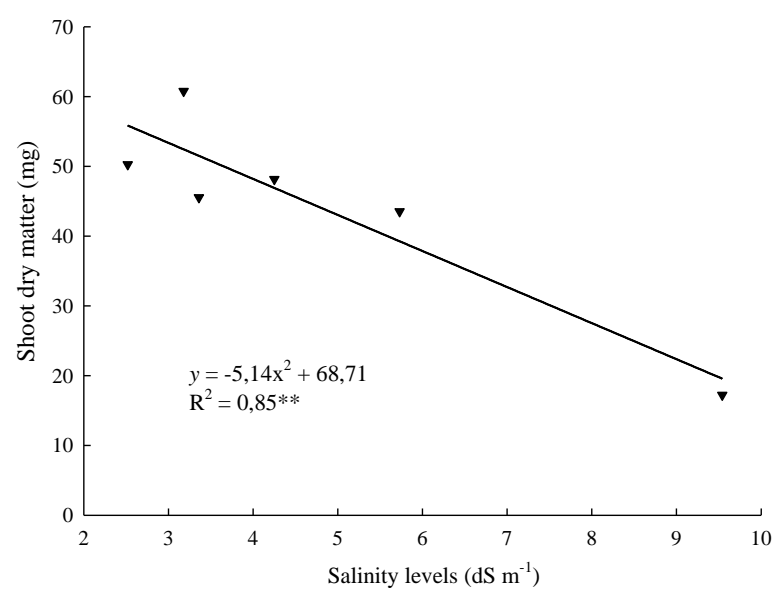

Fig 3. Shoot dry matter of crambe (Crambe abysinica Hochst.) grown under different salinity levels. Botucatu - SP, Brazil, 2012. *, significant at 5\%; **, significant at $1 \%$.
This result disagrees with that of Francois and Kleiman (1990), who found no effect of salinity on vegetative growth up to $8 \mathrm{dS} \mathrm{m} \mathrm{m}^{-1}$. Ionov et al (2013) - planting Crambe Abyssinica seeds originated from the Aral Sea area in Uzbekistan - observed that water with up $3 \mathrm{dS}^{-1} \mathrm{EC}$ might be used in irrigation of crambe with no loss in seed yield. However, when water with 6 and $9 \mathrm{dS}^{-1} \mathrm{EC}$ was used, seed yield was significantly reduced in both years of the experiment, suggesting tolerance to moderate salinity levels (Ionov et al., 2013).

\section{Materials and Methods}

\section{Experimental conditions, experimental design and treatments}

The experiment was carried out under greenhouse conditions between 23 June 2012 and 12 July 2012 at the Department of Crop Science and Plant Breeding at São Paulo State University, located in Botucatu, State of São Paulo, Brazil. The average temperature during the study was $21.4^{\circ} \mathrm{C}$.

The experimental design was a completely randomized block with four replicates. The treatments consisted of six EC levels: $2.50,3.15,3.35,4.25,5.75$ and $9.55 \mathrm{dS} \mathrm{m}^{-1}$. These levels were obtained by adding $0.0,0.1,0.2,0.4,0.8$ and 1.6 $\mathrm{g}$ of $\mathrm{NaCl} \mathrm{kg} \mathrm{kg}^{-1}$ of soil. The EC values were obtained by saturated soil paste extract. The plots consisted of a tray with $5 \mathrm{~L}$ of soil, and each tray contained 40 seeds.

\section{Soil}

The soil used had the following characteristics: $\mathrm{pH} 6.2$ $\left(\mathrm{CaCl}_{2}\right), 31,26,0.2,23,57$ and $80 \mathrm{mmol}_{\mathrm{c}} \mathrm{dm}^{-3}$ of $\mathrm{Ca}, \mathrm{Mg}, \mathrm{K}$, $\mathrm{H}+\mathrm{Al}$, base saturation, and cation exchange capacity, respectively, and $17 \mathrm{~g} \mathrm{dm}^{-3}$ of organic matter, $7 \mathrm{mg} \mathrm{dm}^{-3}$ of $\mathrm{P}$ and 660,70 and $270 \mathrm{~g} \mathrm{~kg}^{-1}$ of sand, silt and clay, respectively. The soil was fertilized with $100 \mathrm{mg} \mathrm{dm}^{-3}$ of $\mathrm{N}$ as ammonium nitrate, $150 \mathrm{mg} \mathrm{dm}^{-3}$ of $\mathrm{P}$ as triple phosphate and $120 \mathrm{mg} \mathrm{dm}^{-3}$ of $\mathrm{K}$ as potassium chlorate. The EC levels were determined after the fertilization.

\section{Plant material}

The cultivar FMS Brilhante was used. This is so far the unique cultivar developed in Brazil, released in 2007. It has an average height of $0.8 \mathrm{~m}$, with herbaceous branched stems; its total cycle takes 90 days and flowering occurs within 35 days. The inflorescence is a raceme type and forms a fruittype capsule. The grain is round, $2 \mathrm{~mm}$ thick, $36-38 \%$ oil (fruit with husk) and $22 \%$ bark. It yields $1000-1500 \mathrm{~kg} \mathrm{ha}^{-1}$, but in experimental plots has yielded up to $2300 \mathrm{~kg} \mathrm{ha}^{-1}$ (Pitol et al., 2010).

\section{Measurements}

Germination and germination speed index (GSI) were evaluated until the 13th day, according to Brazil's rule for seed analysis (Brazil, 2009). Then at the 19th day the shoots were collected, placed in paper bags and dried in a forced air oven at $60^{\circ} \mathrm{C}$ for $48 \mathrm{~h}$ to determine the dry matter. The roots were washed with tap water over a $0.5-\mathrm{mm}$ sieve and were immersed in a 30\% ethanol solution, accommodated in plastic pots with lids, and stored under refrigeration at $2^{\circ} \mathrm{C}$. Roots were digitalized using an optical scanner with a resolution of $300 \mathrm{dpi}$ and analyzed with "Win Rhizo" software (Regent Instrument Inc., Quebec, Canada) to determine the root length, based on the method of Tennant 
(1975). Then the root samples were dried in a forced air oven at $60^{\circ} \mathrm{C}$ for $48 \mathrm{~h}$ to determine the dry matter.

\section{Statistical analysis}

Data were subjected to analysis of variance (ANOVA) $(P<$ 0.05 ) and then, when significant by $F$ test, to regression analysis (linear and quadratic polynomial equations), being the equation chosen according to its significance. Analysis was performed using the software Sisvar (Ferreira, 2010).

\section{Conclusion}

Levels of EC up to $3.77 \mathrm{dS} \mathrm{m}^{-1}$ improved germination of crambe, possibly by an effect of breaking seed dormancy; however, higher levels of EC harmed germination and the GSI. Besides, the vegetative growth was more affected by salt addition than germination. These results indicate that the FMS Brilhante, the first brazilian cultivar of crambe, is moderately sensitive to salinity. The findings of this study are important and can contribute to the advance of researches and cultivation of crambe in Brazil.

\section{References}

Bahmani K, Noori SAS, Darbandi AI, Akbari A (2015) Molecular mechanisms of plant salinity tolerance: a review. Aust J Crop Sci. 9(4):321-336.

Bernstein L, Hayward HA (1958) Physiology of salt tolerance. Annu Rev Plant Physiol. 9:25-46.

Brasil - Ministério da Agricultura, Pecuária e Abastecimento (2009) Regras para análises de sementes. MAPA/ACS, Brasília, DF, 399p.

Carlson KD, Gardner JC, Anderson VL, Hanzel JJ (1996) Crambe: new crop success. In: Janick $\mathbf{J}$ (ed) Progress in new crops. ASHS Press, Alexandria, pp 306-322.

Costa LM, Resende O, Gonçalves DN, Marçal KAF, Sales JF (2012a) Storage of crambe fruit subjected to different drying conditions. Afr J Agricult Res. 7:6274-6280.

Costa LM, Resende O, Gonçalves DN, Souza KA (2012b) Qualidade dos frutos de crambe durante o armazenamento. Rev bras sementes. 34:239-301. (in Portuguese with abstract in English)

Eynard A, Lal R, Wiebe KD (2005) Salt-affected soils. In: Lal R (ed) Encyclopedia of soil science. CRC Press, New York, pp 1538-1541.

Falasca SL, Flores N, Lamas MC, Carballo SM, Anschau A (2010) Crambe abyssinica: An almost unknown crop with a promissory future to produce biodiesel in Argentina. Int $\mathbf{J}$ Hydrogen Energy. 35:5808-5812.

Ferreira DF (2010) Computer statistical analysis system Sisvar - Version 5.3. Lavras, Federal University of Lavras.

Fowler JL (1991) Interaction of salinity and temperature on the germination of Crambe. Agron J. 83:169-172

Francois LE, Kleiman R (1990) Salinity effects on vegetative growth, seed yield, and fatty acid composition of crambe. Agron J. 82:1110-1114.

Franke LB, Nabinger C (1996) Avaliação da germinação de sementes de seis acessos de Paspalum notatum Flügge, nativos do Rio Grande do Sul. Rev bras sementes. 18:102107. (in Portuguese with abstract in English)

Garber SD, Abdalla FH, Mahdy MT (1974) Treatments affecting dormancy in sweet sorghum seed. Seed Sci Technol. 2:305-316.

Ionov M, Yuldasheva N, Ulchenko N, Glushenkova AI, Heuer B (2013) J Agron Crop Sci. 199:331-339.
Liu W, Tollenaar M, Stewart G, Deen W (2004) Response of corn grain yield to spatial and temporal variability in emergence. Crop Sci. 44:847-855.

Maas EV, Hoffman GJ (1977) Crop salt tolerance - current assessment. J Irrig Drain Div. 103:115-134.

Munns R, Tester M (2008) Mechanisms of salinity tolerance. Annu Rev Plant Biol. 59:651-681.

Oplinger ES, Oelke EA, Kaminski AR, Putnam DH, Teynor TM, Doll JD, Kelling KA, Durgan BR, Noetzel DM (1991) Crambe. In: Alternative Field Crops Manual. University of Wisconsin and University of Minnesota. Available in: <https://hort.purdue.edu/newcrop/afcm/crambe.html>. Acess in: July 07, 2016.

Paulose B, Kandasamy S, Dhankher OP (2010) Expression profiling of Crambe abyssinica under arsenate stress identifies genes and gene networks involved in arsenic metabolism and detoxification. BMC Plant Biol. 10:1-12.

Pitol C, Broch DL, Roscoe R (2010) Tecnologia e Produção: Crambe. Fundação MS, Maracaju, 60p.

Qi Y, Yamauchi Y, Ling J, Kawano N, Li D, Tanaka K (2005) The submergence-induced gene OsCTP in rice (Oryza sativa L.) is similar to Escherichia coli cation transport protein ChaC. Plant Sci. 168:15-22.

Rozema J, Flowers T (2008) Crops for a salinized world. Science. 322:1478-1480.

Soil Science Society of America (SSSA) (1997) Glossary of Soil Science Terms. SSSA, Madison, 134p.

Tennant D (1975) A test of a modified line intersect method of estimating root length. J Ecology. 63(3):995-1001.

Tokuisha D, Dias DCFS, Alvarenga EM, Dias LAS, Marin SLD (2007) Tratamentos para superação da dormência em sementes de mamão. Rev bras sementes 29(1): 131-139. (in Portuguese with abstract in English)

Turan S, Cornish K, Kumar S (2012) Salinity tolerance in plants: Breeding and genetic engineering. Aust J Crop Sci. 6(9):1337-1348.

Uddin MI, Qi Y, Yamada S, Shibuya I, Deng XP, Kwak SS, Kaminaka H, Tanaka K (2008) Overexpression of a new rice vacuolar antiporter regulating protein OsARP improves salt tolerance in tobacco. Plant Cell Physiol. 49(6):880-890.

Vinocur B, Altman A (2005) Recent advances in engineering plant tolerance to abiotic stress: achievements and limitations. Curr Opin Biotechnol. 16:123-132. 